\title{
Self-Medication with Cannabis in the Czech Republic from an Anthropological Perspective
}

\author{
Barbora Bláhová ${ }^{1}$ - Miroslav Horák ${ }^{2}$ - Nahanga Verter ${ }^{2}$ \\ 1 Independent researcher, vicechair of Legalizace.cz, E-mail: bara.blahova@gmail.com \\ 2 Mendel University in Brno, Faculty of Regional Development and International Studies, \\ Department of Languages and Cultural Studies, Zemedelska 1/1665, 61300 Brno, Czech Republic
}

Received $3^{\text {th }}$ August 2017; accepted $13^{\text {th }}$ November 2017

\section{SAMOLÉČBA KONOPÍM V ČESKÉ REPUBLICE Z ANTROPOLOGICKÉ PERSPEKTIVY}

\begin{abstract}
ABSTRAKT Tento článek se zabývá samoléčbou konopím (Cannabis sativa L.) v České republice se zaměřením na subjektivní rovinu jejího proživání nemocnými a širší společenský rámec této terapie. Nahliží aktuální situaci, kdy stát selhává v efektivní regulaci konopí jako léku a nemocní často přistupují k ilegální samoléčbě. Od 1. 1. 2017 do 1. 5.2017 byl realizován on-line dotazníkový průzkum mezi záměrně vybranými dobrovolníky, jež byli osloveni prostřednictvím organizací, které poskytují souhrnné informace o této problematice. Výzkumný vzorek tvoří 107 nemocných, kteři užívali konopí a jeho deriváty za účelem samoléčby. Získané výpovědi byly analyzovány metodou zakotvené teorie. Výsledky výzkumu ukázaly, že nemocní, kteří v České republice vyhledávají konopnou samoléčbu považují současnou legální regulaci konopí za nevyhovující. Rostlinu si pro vlastní potřebu nejčastěji opatřují pěstováním a informace o léčbě získávají primárně na internetu. Článek se podrobněji zabývá specifiky konopné samoléčby a jejími dopady na zdravotní stav participantů výzkumu. Obsahuje informace užitečné pro organizace, které se věnují práci s pacienty užívajícími konopí k léčbě.
\end{abstract}

KLÍČOVÁ SLOVA samoléčba; medicínská antropologie; léčebné konopí; cannabis; marihuana

\begin{abstract}
This article is focused on the self-medication with cannabis (Cannabis sativa L.) in the Czech Republic, exploring subjective perception of this treatment by ill persons and its sociocultural framework. It describes a situation when the state fails to effectively regulate medical cannabis and patients often seek practices of self-medication, which remains illegal in the country. An online questionnaire was done from January 1, 2017 to May 1, 2017, in deliberately selected volunteers approached via organizations providing comprehensive information about the issue. The study sample consists of 107 subjects, who used cannabis and its derivatives for self-medication. Using the Grounded theory approach, the results indicate that people who seek cannabis for self-medication in the Czech Republic consider it current legal regulation objectionable. Cannabis plants for self-medication are usually grown at home and people gain information about the treatment primarily online. Considering the experience of respondents, there are common practices of cannabis self-medication described in this article and their impact on the health status of the participants. It contains information useful for the organizations working with medical cannabis patients.
\end{abstract}

KEY WORDS Self-medication; Medical Anthropology; Cannabis; Marijuana

\section{INTRODUCTION}

Cannabis is a cultural plant that has been used by humans for millennia. In the past, it has been commonly used for the treatment, religious ceremonies, and industry. Since the beginning of the 20th century, its glory has gradually faded and in public awareness it has been considered as a risky drug
- marijuana. In recent years, the perception of cannabis has begun to change. The media, scientific papers, and patients report about its significant therapeutic effects, even in cases of such serious illnesses as cancer, epilepsy or multiple sclerosis (Pokrywka et al. 2016; Yasukawa 2014; Devinsky et al. 2014; Corey-Bloom et al. 2012). Many countries are currently regulating legislation on this plant and liberalize its legal regu- 
lation. It seems that cannabis is slowly recovering its importance, although the risks and benefits of its use are still the subject of numerous debates.

In the Czech Republic, cannabis is in a remarkable situation. On the one hand, it is still perceived as a dangerous drug, on the other hand, it therapeutically effects are increasingly being mentioned. In 2013, the use of cannabis in the official medical practice was allowed by the state, but the therapy is costly and often inaccessible. It turns out that ill persons take cannabis treatment into their own hands and approach to illicit practices of self-medication.

The resulting situation has become the subject of our interest. In this article, we focus on the cannabis self-medication in a sociocultural context and explain self-medication as a specific health care strategy, whose importance is increasing hand by hand with an emphasis on individual autonomy (Fainzang 2017).

\section{SELF-MEDICATION AS A CONTEMPORARY PHENOMENON}

The self-medication is currently at the center of interest of physicians, state institutions and social scientists. On one side, there are usually physicians who draw attention to the risks associated with the inappropriate selection of treatment and its potential effects (Bennadi 2013). On the other side, the state institutions on the contrary welcome the initiative of ill persons as a relief from the financial costs of public health care (Fainzang 2017). From the anthropological perspective, the idea of self-medication is always dependent on a specific cultural context, and its choice and form is socially conditioned (Fainzang 2005).

In the public discourse, the self-medication is commonly considered the medicament acquisition without official medical diagnosis, prescription or supervision (Montastruc et al. 1997). This basic definition deserves a more detailed examination. For example, Lecomte (1999) distinguishes between two perspectives on the self-medication. In the broader sense, she considers as self-medication all the actions that occur in response to a health problem and involves a diagnosis of the health conditions and treatment without consulting a physician. In a narrower sense, the self-medication is only about using a medicament that has not been prescribed to the subject. Other authors see these concepts as reductive, with little emphasis on individual involvement. Molina (1988) argues that the patient often comes to a physician and the choice of medicament he asks for is based on his individual decision. An exception is not the case when the patient decides to not obey the physician's advice on correct dosing of the prescribed medicament and therefore as any conduct can be considered selfmedicationto a certain extent, unless the medicament is administered directly by a physician (Van Der Geest et al. 1996). This researchdefines self-medication in a wider sense as a strategy of conduct whereby ill persons on their initiatives acquire and use medicaments to relieve from acute or chronic health problems without prior consultation with a physician.

\section{SELF-MEDICATION AND AUTONOMOUS BEHAVIOR}

In the recent debate about an increasing tendency towards self-medication, the level of individual's autonomy is a key topic. When choosing a specific form of self-care, the subject acts within the purview of certain rules, as the etymology of the Greek word autonomos suggests (auto = individual, nomos = law). However, it is a right of the individual to decide the specific standards to follow (Fainzang 2017).

Currently, the autonomy has become a value that its importance hasbeen exponentially grown and increasingly emphasized. This is naturally reflected in the physician-patient relationship. It seems that the concept of a patient as a subordinate subject that is totally dependent on the physician's decision (Parsons 1951) has already lost its relevance and needs to be considered in new contexts.

As shown on the following pages, in cases where official treatment can not offer a satisfactory solution to their difficulties, patients are willing to exceed not only the physician's recommendations, but also the limits of applicable laws. However, autonomy can not be absolute in the real world. People do not live in a vacuum, and their decisions about the form of selfmedication are always necessarily affected by environmental influences, e.g. by the family, friends, physicians, available information from literature or the media.

In this study, we particularly draw on the Massés theory of free will of the individual. According to this author, there is no purely "theoretical citizen" who is totally deprived of environmental influences. Every person is influenced, even to a certain extent bounded, by family pressures, values and social norms. Autonomy is then always guided and limited by sources of credible and legitimate authority, or by such sources as the individual perceives authentic (Massé 2003).

It is clear that the definition of self-medication can not be simplified to the official treatment prescribed by a physician. It is necessary to take into account also other actions that may have an impact on the motivation to accept it. In these terms, we also approached this topic during the implementation of this research. Its aim was to identify possible sources that constitute the decisions that ill persons make for self-medication. Before dealing with this issue, it is necessary to understand the broader context of this topic.

\section{HISTORICAL CONTEXT}

Self-medication is not only a phenomenon common in the current era, but it extends deep into the past. Until the advent of "modern" medicine, self-medication was a commonly accepted practice in the "Western" world. Not even in the $19^{\text {th }}$ century, physicians were not perceived as the main authority. Patients often co-treated themselves with both home and patented medicaments, and they also tended to follow family, friends, clergy, and healers' recommendations (Thompson 2015). With the increasing availability of medical care, the establishment of a public health system in the beginning of 
the $20^{\text {th }}$ century, and the development of new medicaments and technologies, the public health issue is increasingly in the hands of the state and physicians.

In the Czech Republic, the situation was determined by the political regime and the adoption of the Semašek health care model in the 1950s. Until 1989, the healthcare system was fully in the hands of the state (Zavázalová 1992). The patient's free choice was pushed back to the background and the physician's recommendation became imperative. However, the attitude of of most Western countries has been changing slowly since the 1980s, as we can see in a new emphasis on greater decision-making power of the patient. Also, the self-medication becomes a public health issue. In the Czech Republic, a similar turnaround occurs after the fall of the Iron Curtain. In the following years, it is possible to identify at least three factors that influenced the approach to self-medication: (1) the removal of a number of medicaments from medical prescription that led to the transfer of part of the costs of medication to ill persons. For example, Ibuprofen was removed from medical prescription in the US In 1983. In 1984, the same procedure was adopted by Britain and subsequently expanded across Europe. This tendency also involved antihistamines, as well as other medicaments. Pharmaceutical companies for which a new segment of the market opened that way took advantage from this opportunity, and the emerging advertising campaigns on medicaments supported the idea of self-medication widely (Blenkinsopp - Bradley 1996).

In the Czech Republic, availability of prescription medicaments was increasing in the 1990s. This development is proofed, among others, by the Pharmaceutical Act of 1998, which authorizes the sale of some free medicaments outside pharmacies, and by its further extension in 2006 that has led to the availability of medicaments in chemist's, gasoline pumps and, finally, the possibility of selling them online.

(2) The accompanying phenomenon of this development was not only the increase in costs of medicaments, but also the increase in expected exposure of ill persons to caring about their own health and their independence when deciding on appropriate medication. The emphasis on greater responsibility of citizens for their own health is also evident from the Declaration of Lisbon on the Rights of the Patient:

"Every person has the right to health education that will assist him/her in making informed choices about personal health and about the available health services. (...) The personal responsibility of everybody for his/her own health should be stressed. Physicians have an obligation to participate actively in educational efforts" (WMA 1981).

(3) The boom of information technologies and its easyavailability that was previously almost exclusively in the hands of experts is seen as the third key trend affecting self-medication in recent years. The ability to share treatment experience in online discussion forums with other individuals and to verify diagnostic data from different sources provides ill persons with an unprecedented ease of access to a great deal of information. Consequently, it also brings a number of risks associated with the quality of available data or the media manipula- tion of information by commercial companies, as highlighted by some studies in recent times (Schweim - Ullmann 2015).

\section{PATIENT OR ILL PERSON?}

A new perspective on the issue of ill persons in the context of self-medication necessarily requires a reassessment of the commonly used terms that we usually encounter and its significance is often emotionally impeded. Some authors no longer use the term "patient", as they refer it as a passive individual wholly dependent on the recommended therapeutic program. For example, according to Pierron $(2007,50)$, "the subject is ill when he/she presents biological signals of which the symptomathologic depth affects his/her biography, whereas the subject is a patient when he/she agrees to lose the initiative as regards the illness, handing it to the physician who provides a meaning to the symptom and proposes a therapeutic response".

Thus, if we based on some previous studies about self-medication, the expression "patient" does not seem to be appropriate. Another option for 'patient' is "ill person" proposed by Pierron (2007), which other authors consider to be appropriate for describing the real state of the person (McLaughlin 2009). However, Fainzang (2017) for example thinks that this term also excludes those who take medicaments in a preventive manner and have not been in a situation of acute illness. Therefore, she is inclined to use the term "subject" or "individual" that (in English) take into account the limits of autonomy in decisionmaking given by the sociocultural context.

Another possible term is "user". Nevertheless, its meaning has considerably deviated in the Czech (and English speaking) environment, because of its connection with the use of mind altering substances. For the above-mentioned reasons, we have decided to use the term "ill person" in this article because we find it the most accurate in the context of the issues under study. In a more general text about self-medication, we replace it with "subject" or "individual".

Self-medication is no longer related to the absence of medical care. However, due to increasing autonomy of ill persons, their greater awareness and availability of non-prescription medicaments, the treatment has become a key point of discussion in recent years. It can be declared that self-medication currently represents one of the most widespread strategies in health care. Almost $75 \%$ of all diseases is treated this way. As Habeeb and Gaerhart (1993) suggest, the choice of self-medication is currently rather affected more by the individual's satisfaction with physician they are attending, the costs of the medication and other socio-economic factors, than by the unavailability of medical care.

\section{MEDICAMENT OR DRUG?}

To find out the answer to the question, whether cannabis is a medicament or a drug, it is necessary to deconstruct both terms in the first place. Both of them are 
polysemantic expressions that have undergone a specific historical development. The word "drug" is probably derived from the Dutch word base (drooge = dry) and originally denoted dried organic material used to treat health problems (Zábranský 2003). This concept is likely to result in the original pharmacological definition where any substance containing molecules with physiological effects on the human organism is considered as a drug (Brody et al. 1998). In the current discourse of social sciences, a definition of drug by Presl prevails. Presl considers it as any substance that complies with two basic characteristics: (1) it has a psychotropic effect and (2) it can cause addiction (Zábranský 2003). Generally speeking, the term drug then typically refers to anything that generates strong fixation.

Similarly, the term "medicament" can be perceived in various ways. Pharmacology defines it as a pharmaceutical and medicinal product adapted to the final form in which it is used and administered to a patient (Katzung 1994).

In social sciences, the concept is used ina broader term, reflecting its importance in a particular sociocultural context. It shows that there is a significant overlap between what is considered a medicament, ailment and poison (Hugh-Jones 1993; Etkin - Ross 1982).

In the outlined perspective, there is no universally acceptable answer to the given question, as its formulation is problematic as well. Not only cannabis, but many other commonly available and used plants can be described from the point of view of all the definitionsmentionedabove, because they gain various meanings in different contexts. Therefore, we need to ask when and under what conditions cannabis is perceived as a drug.

\section{RELEASE OF LEGISLATION}

The revitalization of cannabis in societies and the liberalization of legislation have occurred in recent years, when more countries at different degree permit an access to its legal use for therapeutically purposes. However, in Europe, it is still against the law in some countries such as the Czech Republic, Germany, the Netherlands and Italy. Nevertheless, cannabisbased medicaments are authorized in France. In Belgium, the cultivation of one cannabis plant for their personal use is allowed. Medical cannabis is also legal in the UK.

A different situation is paradoxically in the cradle of cannabis prohibition. The United States has embarked on a clear path of legalization, and cannabis is currently legal at a varying degree in thirty countries. In Washington, Oregon, Nevada, California, Colorado, Alaska, Maine, and Massachusetts, cannabis is even allowed for recreational use, which has generated unprecedented attention and seemed to have a major impact on the economy of some states in the country (Light et al. 2016).

The Czech Republic also legalizedcannabis for medical purposes four years ago. Manipulation with cannabis having tetrahydrocannabinol (THC) content higher than $0.3 \%$ is regulated by the Act on Addictive Substances 167/1998 Coll.
In 2013, an amended Act No. 50/2013 Coll., also known as the "Cannabis Amendment", was published. It contains regulations on the use of cannabis for therapeutically purposes. Unauthorized possession of cannabis for the individual use is currently defined by the Czech law as unlawful and punishable in all cases, except for registered patients.

In other cases, the law distinguishes between possession of socalled small quantities of cannabis for individual use, which is assessed according to the Misconduct Act 200/1990 Coll. and punishable by a fine of up to $15.000 \mathrm{CZK}$. Holding more than a small quantity falls under the Criminal Act 40/2009 Coll. and the subject may be imprisoned for up to six months for violating the law. Plant cultivation for individual use remains illegal in all cases.

\section{CANNABIS AND ADDICTION}

Addiction syndrome is defined by the American Psychiatric Association (2013) as a set of behavioral, cognitive and physiological phenomena that develops on the basis of repeated use of a substance and typically involves at least three of the following symptoms: craving, withdrawal syndrome, neglecting other activities due to consumption, and constant use despite demonstrating negative effects. There is usually distinguished between physical addiction, when negative somatic symptoms after drug withdrawal, and psychic, which represents much more complex and often a multi-layered problem.

Addiction is also defined as perceives serious brain disease, characterized by a compulsive drug use despite its negative effects. In this case, addiction is perceived as a disease because the drug changes functioning of the brain, resulting to most pathological behavior (NIDA 2016). For more analysis about the concepts of addiction see Horák (2014).

Statistically, studies by Budney et al. (2007) show that the risk of addiction to cannabis might develop in approximately $8 \%$ of users. This is far lower if compared with the risks in alcohol (22.7\%), nicotine $(67.5 \%)$ or cocaine $(20.9 \%)$ consumption (Lachenmeier - Rehm 2015). The highest risk of addiction is recorded in adolescents $17 \%$ and continues to decline with age (Anthony 2006).

With a closer look at above mentioned definitions and numbers, we need to ask to some questions: what extent are they socially relevant? How is it possible to quantify the average risk of such a complex issue as addiction?

The main problem lies on perceiving drug as the primary trigger of addiction. Furthermore, addiction is conceived as a disease and addicted person as its victim. Current research shows that the truth is probably elsewhere: addiction often arises as part of complex processes that primarily involve close relationships (Dingle 2015).

Branch (2011) argues that addiction is also largely influenced by the decision and will of the user. The deep-routed perception of addiction as a drug-related disease is not realistic according to scientific studies (Holden 2012). It also takes a responsibility for the health from the hands of an addict. This 
can be often counterproductive in the therapy. If we want to assess the real danger of cannabis, it would be more appropriate to focus on the social danger of using it than on the potential of addiction.

According to the information above, the results of statistics demonstrating the risk of cannabis due to the emergence of addiction do not appear to have any significant value. A more appropriate way of assessing the real hazard of addictive substances could be to assess the negative impacts of their use in the wider social context and two perspectives: how does the use influence individuals and what are the risks of the use for the society (e.g. criminality or the symptoms of acute intoxication). Studies that are in line with this view (Nutt et al. 2010) demonstrate that the risks of cannabis use are two thirds lower than the ones of legal alcohol.

Studies by Morral et al. (2002) do not confirm any causal link between cannabis and hard drugs usage. This also disputes the thesis that cannabis is a gateway to drug abuse. On the contrary, contemporary studies (Morgan et al. 2013) suggest that cannabis may have positive effects on the treatment of drug addictions.

\section{HEALTH RISKS OF CANNABIS USE}

As noted above, addiction is a complex phenomenon that can not be analyzed separately from the sociocultural context. However, it has been proven that cannabis addiction in longterm users actually arises and that temporary physical and psychological symptoms such as loss of appetite, insomnia, anxiety or depression may occur during discontinuation. It is likely that these symptoms are associated with the habituation of the organism to the regular intake of cannabinoids and are probably caused by the effort of the endocannabinoid system to bring about equilibrium. These symptoms usually peak between 5-6 days after the last use, and usually fall within two weeks (Budney - Hughes 2006).

As far as other risks are concerned, there is often a link between cannabis use and cognitive impairment. It has been demonstrated that it temporarily reduces in users (Shrivastava et al. 2011; Pope 1996).
Another issue is the possible development of psychosis, where the use of cannabis appears to be risky, especially in connection with the genetic predisposition to this disease. However, the exact mechanism of how it originates remains controversial (Hall 2008; 2000). A higher risk of psychosis may involve the use of highly potent cannabis varieties (Englund et al. 2017). Both areas are the subject of current research. The above-mentioned studies argue that the riskiest is the use of the plant in adolescence.

Major risks are associated with such a form of administration when cannabis is smoked. It is particularly problematic to mix it with tobacco in cigarettes. Tobacco is carcinogenic in contrast to cannabis smoke (Melamede 2005). Cannabis contains about 1500 different chemicals, including some known carcinogens. Arguably, tobacco smokers experience higher incidence of cancer than Cannabis smokers (Backes 2016).

Undoubtedly, the risks of cannabis use exist. Notwithstanding, considering its increasing popularity, especially for healing purposes, it is necessary to analyze them consistently. It is paramount to propose risk reduction strategies that may well lead to safer use of cannabis and treatment. Above all, some stereotype concepts of cannabis must be abandoned, as they are clearly not supported by relevant evidence.

\section{METHODOLOGY}

Research on cannabis self-medication in the Czech Republic was done between January 1, 2017 and May 1, 2017 and was based on a qualitative survey questions. A detailed description of the research framework is presented in the Table 1.

The questionnaire was created online on Google Forms and subsequently published on websites and social networks of Czech organizations that deal with cannabis issues. We supposed that these sites may be visited by ill persons for cannabis treatment. Specifically, the following platforms were selected: website of the association Legalizace.cz; website of the Legalizace magazine operated by Legal Publishing Ltd.; and patient association KOPAC.

We also sent a questionnaire via e-mail to people who we have

\begin{tabular}{|l|l|}
\hline Strategic research question & How do people in the Czech Republic treat themselves with cannabis? \\
\hline \multirow{2}{*}{ Partial research questions } & Why ill people self-medicate with cannabis? \\
\cline { 2 - 2 } & What are the specifics of cannabis self-medication? \\
\cline { 2 - 2 } & How is the self-medication affected by its illegality? \\
\hline Research objective & Experiences of ill people who self-medicate with cannabis in the Czech Republic \\
\hline Research sample & 107 respondents \\
\hline Research strategy & Emic Approach \\
\hline Research method & Qualitative questionnaire \\
\hline Nature of collected data & Responses in a qualitative questionnaire \\
\hline Method of data analysis & Grounded theory \\
\hline
\end{tabular}

Tab. 1. Research framework (source: own processing). 
known, thanks to the previous personal contact, are self-medicating with cannabis and through them to other potential respondents. Therefore, the choice of respondents was deliberate, by self-sampling and the snowball sampling (Bernard 2006). The questionnaire was filled in by anonymous volunteers.

The questions about the characteristics of treatment were open and the respondents had an unlimited number of characters for a detailed description of their response. Questions to retrieve research sample data and filter questions were formulated as closed or semi-closed and were not further analyzed. Research, design and control issues were also used (Reichel 2009). When constructing them we have taken care of their comprehensibility. All sentences and a neutral language were used without emotionally colored terms (Sheble - Wildemuth 2009).

The questionnaire was completed by 111 respondents. 4 respondents were excluded from the research sample because they filled the questionnaire for the third person. Finally, 107 people participated in the research.

The research sample was comprised of respondents of Czech nationality, of all ages. Predominant individuals aged 20-30 years $(26 \%)$, followed by $30-40$ years $(21 \%), 60$ years and over (19\%), 40-50 years (17\%) and 50-60 years (10\%). The least represented were respondents under the age of $20(7 \%)$. The prevailing family status of respondents was single (49\%). $37 \%$ of subjects were married, $13 \%$ divorced, and $1 \%$ widowed. The vast majority of respondents (71\%) completed secondary education, $17 \%$ university and $12 \%$ primary education. Among the respondents were students, retired, programmers, accountants, bartenders, technicians, police officers, housewives, self-employed, builders, technicians, managers, translators and proofreaders, artists, chefs, salespeople, teachers, architects, scientists, and entrepreneurs.

The collected data was analyzed in Microsoft Excel based on the Grounded theory approach (Strauss, Corbin, 1998). For all responses, the so-called open coding was first performed by assigning certain codes (i.e. analytical categories) to the individual units of analysis (defined by the extent of one field for an open question).

Assignment of codes was performed both on the basis of the localization of main topics in the text and their relating to the research questions, and on the basis of the previous knowledge of the topic from literature and personal experience. Codes created during open coding were organized with the intent of revealing predefined topics in the text. After open coding, all codes were copied to a separate worksheet, and each of them was assigned by the respondent's identification tag giving the ability to track coded responses (e. g. C098). The next step was the so-called axial coding when the individual codes were sorted into categories that define their meaning in the context. We chose from the six categories proposed by Strauss and Corbin (1998), such as phenomenon, causal conditions, intervening conditions, action strategies, consequences and context.

Furthermore, we have sorted the codes from open coding according to their kinship into the so-called coding families, i.e. parent codes (Hendl 2008). This way the pillars of grounded theory were gradually established. The code families became the basis of a paradigmatic model of our theory.

Subsequently, we continued with the so-called selective coding, where the main topics of the whole research and the relationships between them were identified. We determined them on the basis of causal relationships between the categories found within the axial coding and also according to the groundedness and density of open codes. All the codes with more than 20 occurrences were expected to be statistically significant. However, 10 occurrences of the code were taken into account for selection process.

\section{RESULTS}

During the open coding, a total of 1034 codes were created. The Figure 1 illustrates 6 code families that were most grounded in responses, i.e. the largest number of other codes was connected to them.

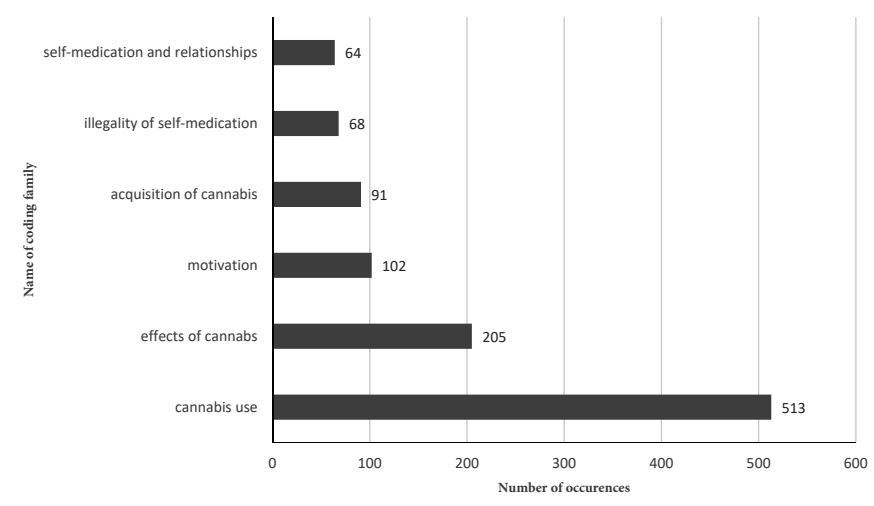

Fig. 1. Most grounded code families derived from responses (source: own processing).

The Figure 2 shows the most frequent code families, i.e. code families with the highest density.

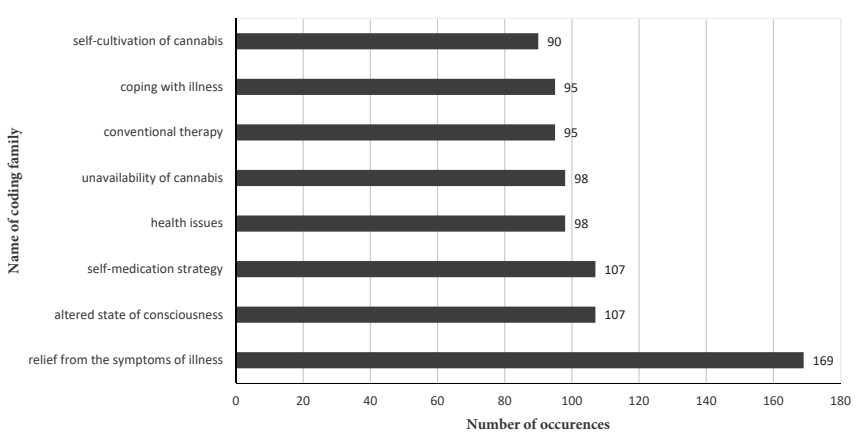

Fig. 2. Code families with the highest density (source: own processing).

Based on the results, we have created a paradigmatic model of the grounded theory that explains the basic relationships between the code families (see Figure 3).

Different motives for cannabis use stem from symptoms of different illnesses and lead to an effort to obtain cannabis. The 


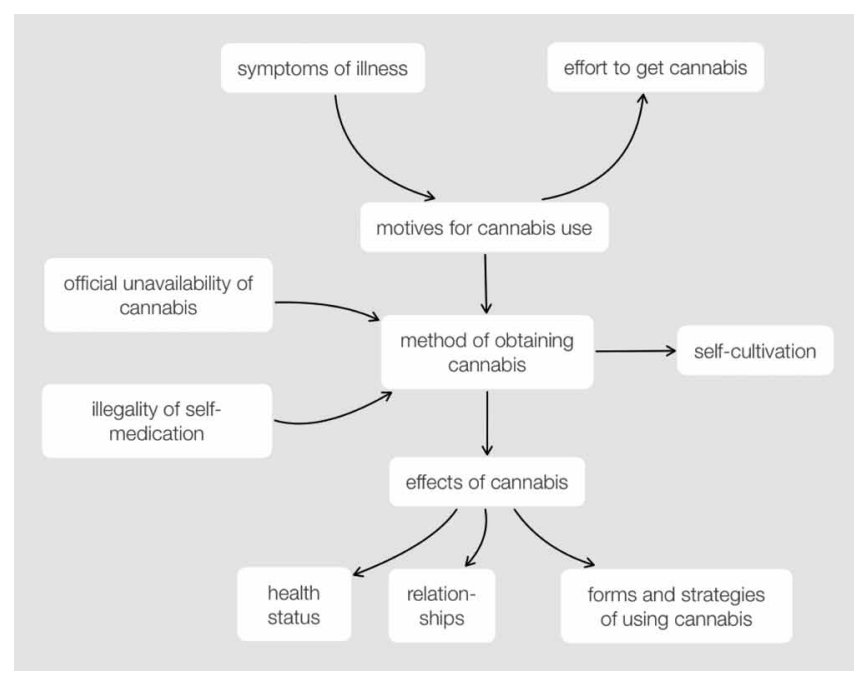

Fig. 3: Paradigmatic model of the grounded theory (source: own processing in MindNode).

method of obtaining it is affected by its official unavailability and the illegal practice of self-medication. In the majority of cases, it results in self-cultivation. Effects of cannabis, typically relieving from symptoms of the illness, reversely affect the health status of individuals, their relationships with the environment, and also the forms and strategies of using the substance to self-medicate.

The results obtained from the primary research of this current study are interpreted in detail in following subchapters. Because of the limited extent of this article, these subchapters are exclusively focused on the most grounded and dense code families.

\section{CANNABIS USE}

The findings show codes related to the use of cannabis as the most frequent in the statements of respondents. It reveals two major strategies of self-medication within the context of their inclusion into everyday life of the informants. They are often opposed to each other and cause conflicting situations. It is (1) the use of cannabis in response to acute symptoms of the illness and (2) the effort to restrict its use in spare time.

The current decision to use cannabis is often triggered by the onset of acute discomfort related to the illness and the effort to eliminate it. An entrepreneur suffering from a severe depression says: "Every morning I get up and I think I'm useless. It makes no sense to live. Fear has taken hold of my life and mind, which I desire to end it. So I smoke some cannabis, II am relieved as those thoughts and feelings disappear" (C098). An office worker suffering from eating disorders said "in the morning, I have a problem with food intake, any mouthful causes me to vomit. 2-3 tokes of cannabis and after about 30 minutes the problem will go away and I can eat without difficulty. Similarly, sometimes I am reluctant to eat inthe evening. It's not a day-today rule" (C008).
The key moment when someone decides to use cannabis was describedby a student suffering from neurotic depression: 'Depression affects my personal and working/student life. The point is that if it comes to me, I'm not capable of physical activity. I am overwhelmed and mostly crying - perhaps unreasonably. I can't think reasonably and "everything is wrong". Most of these thoughts come to me in the late afternoon after a busy day. (...) If I have an anxiety attack, my chest really hurts and I feel tied, sometimes I gasp. After smoking marijuana, I feel relief immediately, and the feeling in my chest recedes. Consequently, I communicate very well, and I am in much better mood although I can't say the anxiety disappeares 100\%' (C072).

One of the respondents suffering from multiple sclerosis states that "in the daytime, if I find it difficult behave in a normal well, which leads me to roll a joint and I smoke it, or I use a vaporizer when I'm in the house" (C096).

The onset of undesirable effects of conventional therapy might also trigger the use of cannabis. This argument was illustrated one of the respondents with multiple sclerosis: "Administering the healing injection, Avonex, helps me manage flu-like symptoms, toothaches and chills. It deepens on my sleep, so I feel a lot more relaxed and have enough strength the next day. Occasional$l y$, it cures headaches. Overall, it improves my mood. (...) Instead of pills I use a vaporizer and the results are amazing" (C025).

The second dominant strategy of the patients is their effort to reserve self-medication for spare time when it is not necessary to perform activities that require concentration, especially outside of working hours. The effects of some plants influence the motivation. A technician suffering from Crohn's disease describes his self-medication practice as follows: "I use a pinch-size extract in meals, mostly in the evening, because I always feel sleepy using it in the morning" (C043).

Another respondent stated: "[I use cannabis] in the evening before bedtime, especially when I do not have to work in the morning or at night if I suffer from insomnia" (C026). Another technician with Tourette's syndrome has reconstructed the common situation where cannabis is used: "Ideally, when it's a quiet evening, and I know I do not have to drive anywhere, I roll a cigarette or use a vaporizer" (C064).

A guard who has been affected by multiple sclerosis said: "I try to do most of my work in the morning, when my condition is very good. I usually use cannabis after lunch. Then I don't feel like working anymore, but after an hour of persuasion I can continue" (C096). A programmer suffering from anxiety and depressive disorder uses cannabis only in the evening. He mentioned: "I use cannabis only before bedtime, and I do not feel any negative symptoms during the day. The most persistent effect is a mild muscle relaxation" (C100). The situation where conflicting strategies and attempts to integrate both approaches occur illustrates the testimony of a chef suffering from the chestnut-drying: "Assuming I have to work from $7 a m$ to $4 \mathrm{pm}$, and I'm in pain, then no cannabis, but from 2 up to 5, or 6 pills of some strong medicament that will occasionally help a little. It is followed by the reluctance to eat and headaches. Most of the pains persist, and I'm forced to leave the work earlier. When I leave work at 4pm, I hurry home 
to roll a joint. The effect after smoking is mostly instantaneous [from $1 / 3$ to $1 / 2$ of it]. After about 1 hour I feel free and relieved of all pains, so I might just have some food immediately. Most of the time, I roll the second joint and smoke during the evening before going to bed [around midnight]" (C044).

\section{RELIEF FROM THE SYMPTOMS OF ILLNESS}

The basic feeling in describing the effects of self-medication with cannabis is a relief. This relief has been referred to in descending order according to the groundedness of codes: pain, stiffness, loss of appetite, insomnia, anxiety, depression, and skin problems. The effects of cannabis were described in a comprehensive manner, and individual effects can not be separated. For instance, one of the respondents' who has multiple sclerosis describes the immediate effects after using it for first time: "Perhaps for the first time I ate very well after a month, my pains disappeared and I fell asleep as a baby. I woke up in the morning with a pleasant feeling, and I did not think I was ill and that chemo [therapy] and radiation was waiting for me" (C009).

Cannabis helps some patients manage the conditions associated with chemotherapy. Apart from pain, it is mainly anorexia or nausea. This is also reported by a businesswoman who used cannabis during the treatment of lymph node cancer:

"After chemotherapy, most patients suffered much more than me, they could not eat any of their favorite meals. I could eat wellafter using marijuana. I did not suffer from pain or depression. (...) Thanks to cannabis, I was able to withstand chemos much easier than patients I met in oncology" (C037).

The most common indication for cannabis use is pain, especially in chronic conditions. There were descriptions of relief from more common conditions, from a minor pain (e.g. in the case of common colds) to a long-lasting intense pain included in responses. A locksmith who uses cannabis to treat chronic pain and migraines said: "[After the use of cannabis], the terrible headaches during migraine that forced me to swallow a lot of medicaments would disappear. Now it takes just about 10 minutes to vaporize the cannabis, and the pain is over. Because I am an athlete, tension and muscle cramps disappeared as well" (C005).

Cannabis is used typically to achieve both relief in acute pain and preventative maintenance of mild discomfort. This was described by a businessperson who suffers from a chronic pain: "Since I have been using cannabis, the pain is less intense and less common. If the pain appears, cannabis will reduce it to a very tolerable level. Before I started using cannabis, I had to take painkillers up to two times per month. Now I use it once a year. (...) I use [cannabis] in case of acute pain, as well as in pain prevention" (C020).

The use of cannabis for the treatment of acute conditions is described by another respondent as follows: "It relaxes the muscles, soothes the mind and completely suppresses all the other symptoms of the illness such as joint pain, skin hurt and headache" (C026).
Respondents confirmed that cannabis helps in curing insomnia problems. For instance, a businessperson who suffers from asthma states: "I can sleep, I can think without dark ideas. I have the appetite again and the substance usually helps relieve my pain" (C093).

There were also descriptions of relief from dermatological problems, when cannabis is indicated frequently, represented in responses. The positive results of the cannabis ointment in the treatment of atopic eczema were described by one of the respondents as follows: "[Cannabis has positively affected my conditions as] eczema has disappeared. Also, problems with dry skin on the face are rarely seen" (C022). Similar effects were confirmed by another respondent: "Symptoms of atopic eczema were almost immediately alleviated, until complete cure. In depression, I felt a great sense of relief after internal tension was reduced" (C016).

Self-medication with cannabis has a significant effect on psychological conditions, such as anxiety disorders and depression, as well as the mood improvement and overall sense of well-being. Most especially, the statements about more serious illnesses, the onset of this effect has been greatly welcomed. A respondent suffering from multiple sclerosis said: "In particular, thanks to cannabis Ididn't mind too much that psychological state where I saw that everything was ending for me and my life was drowning. Thanks to cannabis, I overcame a really difficult time. (...) I have reconciled myself to the illness long time ago and I attribute it to cannabis. Without it, I would be far off to accept being sick and unable to do this and that. It has mostly helped me in this way" (C009).

Similarly, our respondents' stess that cannabis is also effective in the treatment of traumatic conditions, including posttraumatic stress disorder. In the same vein, a translator argues that, self-medicating with cannabis relieves of chronic fear and anxiety. She describes her first experience with self-medication: "I felt my mind brighten and the energy accumulated [fear and anxiety] can be breathed, and I can go back to my normal life. I can lie down and relax (which stress regularly doesn't allow me) and in an hour the effect could fade away. It was important for me to open the psyche, to get on a deeper plane, to drain a little of the fear that I have had due to traumatic events. The next day, I didn't feel the usual stress. It seemed to me that I have a bright mind that I have got it all together. After a long time, I felt satisfied and happy" (C001). Therefore, it has shown that cannabis has a potential to give patients a sense of relaxation not only on the physical, but also on the psychological level.

\section{CONCLUSIONS}

This article deals with the issue of self-medicating with cannabis in the Czech Republic. We tried to clarify the nature of this phenomenon and the processes that have formed it. In the context of medical anthropology, we outlined the issue of illness and healing with a focus on the changing role of the patient, who is not only a passive subject of medical care, 
but often takes a decisive initiative on matters of their health. It is revealedthat self-medicating with cannabis has not been legalized in the Czech Republic.

Cannabis is a controversial plant. It has undergone a rich cultural development and is often perceived not only as a medicament, but also as a dangerous drug. In the article, we reconstructed the origins of both these views and explained their causes and consequences in a sociocultural context. The risks and the healing effects of this plant from the point of view of contemporary science were also addressed. Also, an attempt was made to evaluate their relevance in relation to self-medication.

Based on the current scientific knowledge on cannabis use, an online questionnaire survey was conducted to find out how and why people in the Czech Republic are self-medicating with cannabis. In total, the data from 107 patients, who provided us with valuable information about the nature of this practice in the context of current legislation, was obtained. The primary motivation for choosing cannabis as a therapeutic agent were the negative symptoms of an illness from which conventional treatment often failed to cure effectively. The motivation has been formed by previous knowledge of this plant, information obtained on the Internet, and recommendations from the families and close relatives. The results demonstrate that cannabis is known in the Czech Republic and many ill persons or their relatives had prior experience with it before treatment. The self-medication is aprochaed because of the unavailability of medical cannabis in the official way, especially for its high price, the low number of physicians willing to prescribe it, and the lack of it suitable varieties in pharmacies.

The main way to obtain cannabis is self-cultivation, which is more affordable, but the law prohibits it. The illegality of cultivating and possessing cannabis for selfmedication is accompanied by fear of criminal sanctions, feelings of injustice and criticism of establishment. The principal way of cannabis use represents the smoking of a dried plant. This finding is problematic because there are compounds with negative effects on human health produced during its combustion. Among reasons for smoking cannabis are easier dosing and regulation of the effect. This could be replaced by a safer method of vaporization, already approached by some ill persons.

The use of cannabis leads to relief from some health problems, including pain, spasticity, loss of appetite, insomnia, anxiety and depression. A relief was described both on physical, and mental level.

The greatest social concern about cannabis treatment represents the psychoactive effects of this plant, especially in the case of incorrect dosing and the overuse of cannabis, unpleasant states may occur. These include feelings of disorientation, anxiety, fatigue and hallucinogenic sensations. However, after the effects had subsided, these symptoms disappeared without any further consequences.

The neglected fact is that the altered state of consciousness caused by cannabis use may have therapeutic potential. It can help patients relieve discomfort and lead to a positive perception of their illness. It contributes to improving the subjective perception of quality of life and coping with an illness.

In respect to the progressive legalization in the United States of America, the gradual liberalization of legislation in other countries, and the rapid advancement of scientific research in cannabis, we expect that this plant may increasingly become available and commonly used as a medicament in the Czech Republic. In order to make this medication really safe, it is necessary to inform the public and physicians objectively about benefits and risks of this therapy and how to optimize them. In particular, better state regulation and improved availability of cannabis for therapeutic purposes should be ensured. It is the illegality of self-medicationseems to be the greatest threat that cannabis poses to ill persons.

\section{LIMITS OF RESEARCH AND DISCUSSION}

This research has a number of limitationspartially due to the method of data collection, the nature of the research sample and the chosen analytical method. We have identified 5 of them as briefly explained below:

(1) The questionnaire survey could lead to a more brief form of some statements and did not allow motivating the participants to clarify certain formulations as a semi-structured interview would do (Hendl 2008). We considered this factor when choosing a methodology. For the implementation of the questionnaire we decided to increase the variability of the research sample and to map the situation of as many ill persons as possible with different types of health problems, without any limitation of the site or a particular social group. Because of this data collection method, we did not have the opportunity to take part in participant observation of specific situations and circumstances of self-medication, or to determine the socio-economic status of ill persons. It appears that these circumstances are influencing the selfmedication (Raynaud 2008).

(2) Another limit was caused by the form of the questionnaire. The online version required that all respondents have access to the computer, the Internet and, of course, a degree of technical ability. For some ill persons, particularly those who suffer from impairment of motor functions, filling in the questionnaires could be physically impossible. The form of online survey is also likely to reduce the age profile of the research sample. (3) The manner in which the questionnaire was disseminated could also play a role in sampling. Due to its publication on the websites of specific organizations, it is possible that some data could be biased.

(4) Limitations also arise from the fact that the subject of study was illegal behaviour in the Czech Republic. Therefore, some respondents have refused to answer the question about how they obtain cannabis. Since cannabis use is illegal in the country, it is likely that also played a role in in some of their responses by discouraging some ill persons from par- 
ticipating in the research even though we have tried to limit the risk of concealing information about illegal behavior by both anonymity and survey dissemination through the Legalizace.cz association. The association has provided the research with the aegis. This organization is at the center of interest in cannabis treatment in the Czech Republic. It provides legal counseling for long-term patients, seeks reform of cannabis laws, disseminates information on treatment, and provides patients with free cannabis seeds for self-cultivation. The credibility of the association might have motivated ill persons to participate and provide some sensitive data related to self-medicating with cannabis.

Additionally, the way the questionnaire was published is likely to have also encouraged ill persons who are skeptical aboutthe treatment, to particiapate in this present research. That is why we also asked KOPAC Patient Association to disseminate the questionnaire, because it motivates the ill persons to use medical cannabis prescribed by medical professionals.

(5) Limitations also arise from the chosen type of data analysis based on the Grounded theory method, which operates with the intensity of statements. The data do not have to necessarily reflect the nature of the fact being investigated, but only what the participants decided to communicate in their responses. This could also be affected by the structure of the questionnaire, necessarily limited only to a certain range of topics. As a consequence, the results may not adequately reflect the situation on ground.

The purpose of this research was to obtain data of a qualitative nature from the widest possible sample of ill persons who self-medicate themselves with cannabis in the Czech Republic and discover the basic factors and strategies in their health care. To what extent has this been done, remains a question. In all cases, the results demonstrate that self-medicating with cannabis is a topical issue in the Czech Republic that is worth studying. For a better understanding of motivation for cannabis self-medication and its nature, further studies should focus on the context in which it takes place. Of course, it would also be interesting to analyze those situations where cannabis medications are freely available to patients.

\section{CONFLICTS OF INTEREST}

No conflict of interest.

\section{ACKNOWLEDGMENTS}

This article is supported by the Internal Grant Agency of the Faculty of Regional Development and International Studies, Mendel University in Brno, as part of the project titled "Sociocultural Aspects of Drug Addiction Treatment" (ID: FRRMS_ IGA_2017/002). The authors thank for the funds provided.

\section{REFERENCES}

American Psychiatric Association (2013): Diagnostic and Statistical Manual of Mental Disorders. Arlington: American Psychiatric Publishing. https://doi.org/10.1176/appi.books.9780890425596.744053

Anthony, J. C. (2006): The epidemiology of cannabis dependence. In: Roffman, R. A. - Stephens, R. S. (Eds). Cannabis dependence: Its nature, consequences and treatment. Cambridge: Cambridge University Press, 58-105.

Backes, M. - Weil, A. - Kozák, J. (2016): Konopná lékárna: praktický průvodce světem léčivé marihuany [Cannabis pharmacy: A practical guide the world of healing marijuana]. Olomouc: Fontána.

Bernard, H. (2006): Research methods in anthropology: Qualitative and quantitative approaches. Lanham: Altamira Press.

Blenkinsopp, A. - Bradley, C. (1996): Patients, society, and the increase in self medication. BMJ (Clinical Research Ed.), 312(7031), 629-632. https://doi.org/10.1136/bmj.312.7031.629

Bennadi, D. (2013): Self-medication: A current challenge. Journal of Basic and Clinical Pharmacy, 5(1), 19-23. https://doi.org/10.4103/09760105.128253

Branch, M. N. (2011): Drug addiction. Is it a disease or is it based on choice? A review of Gene Heyman's Addiction: A disorder of choice. Journal of the Experimental Analysis of Behavior, 95(2), 263-267. https://doi. org/10.1901/jeab.2011.95-263

Brody, T. - Larner, M. - Minneman, K. P. (Eds.) (1998): Human pharmacology. Molecular to clinical. New Jersey: Prentice Hall.

Buclin, T. - Ammon, C. (Eds.) (2001): L'automédication: pratique banale, motifs complexes. Genève: Médecine et Hygiène, Cahiers Médico-Sociaux.

Budney, A. J. - Hughes, J. R. (2006): The cannabis withdrawal syndrome. Current Opinion in Psychiatry, 19(3), 233-238. https://doi.org/10. 1097/01.yco.0000218592.00689.e5

Corey-Bloom, J. - Wolfson, T. - Gamst, A. - Jin, S. - Marcotte, T. D. Bentley, H. - Gouaux, B. (2012): Smoked cannabis for spasticity in multiple sclerosis: A randomized, placebo-controlled trial. CMAJ, 184(10), 1143-1150. https://doi.org/10.1503/cmaj.110837

Dingle, G. A. - Cruwys, T. - Frings, D. (2015): Social identities as pathways into and out of addiction. Frontiers in Psychology, 6(NOV). https://doi. org/10.3389/fpsyg.2015.01795

Devinsky, O. - Cilio, M. R. - Cross, H. - Fernandez-Ruiz, J. - French, J. Hill, C. - Katz, R. - Di Marzo, V. - Jutras-Aswad, D. - Notcutt, W. G. Martinez-Orgado, J. - Robson, P. J. - Rohrback, B. G. - Thiele, E. Whalley, B. - Friedman, D. (2014): Cannabidiol: Pharmacology and potential therapeutic role in epilepsy and other neuropsychiatric disorders. Epilepsia, 55(6), 791-802. https://doi.org/10.1111/epi.12631

Englund, A. - Freeman, T. P. - Murray, R. M. - McGuire, P. (2017): Can we make cannabis safer? The Lancet Psychiatry. https://doi.org/10.1016/ S2215-0366(17)30075-5

Etkin, N.L. - P.J. Ross. (1982): Food as medicine and medicine as food: An adaptive framework for the interpretation of plant utilization among the Hausa of Northern Nigeria. Social Science and Medicine, 16, 1559-1573.

Fainzang, S. (2005): Religious attitudes toward prescriptions, medicines, and doctors in France. Culture, Medicine and Psychiatry, 29(4), 457-476. https://doi.org/10.1007/s11013-006-9003-5

Fainzang, S. (2017): Self-medication and society: mirages of autonomy. Milton Park, Abingdon, Oxon: Routledge.

Hall, W. - Degenhardt, L. (2000): Cannabis use and psychosis: a review of clinical and epidemiological evidence. The Australian and New Zealand Journal of Psychiatry, 34(1), 26-34. https://doi.org/10.1046/j.1440$-1614.2000 .00685 . x$

Hall, W. - Degenhardt, L. (2008): Cannabis use and the risk of developing a psychotic disorder. World Psychiatry, 7(2), 68-71. https://doi. org/10.1002/j.2051-5545.2008.tb00158.x

Hendl, J. (2008): Kvalitativní výzkum: základní teorie, metody a aplikace [Qualitative research: Basic theories, methods and applications].Praha: Portál.

Holden, T. (2012): Addiction is not a disease. CMAJ: Canadian Medical Association Journal, 184(6), 679. https://doi.org/10.1503/cmaj.112-2033

Horák, M. (2014): A brief history of drug abuse, addiction concepts and community treatment. In Human And Social Sciences at the Common Conference 2013. Žilina: Publishing Society, 157-160. 
Hugh-Jones, S. (1993): "Food" and "Drugs" in Northwest Amazonia. In Tropical Forests, People and Food: Biocultural Interactions and Applications to Development. Carnforth, Lancs: UNESCO, 533-548.

Katzung, B. G. (1994): Základní a klinická farmakologie [Basic and clinical pharmacology]. Praha: H\&H.

Lachenmeier, D. W. - Rehm, J. (2015): Comparative risk assessment of alcohol, tobacco, cannabis and other illicit drugs using the margin of exposure approach. Scientific Reports, 5(1), 8126. https://doi.org/10.1038/ srep08126

Lecomte, T. (1999): Chiffres de l'automédication en France et à létranger. In Queneau, P. (Ed.) Automédication, autoprescription, autoconsommation. Paris: John Libbey, 49-56.

Light, M. - Orens, A. - Rowberry, J. - Saloga, C. W. (2016): The economic impact of marijuana legalization in Colorado. Denver: Marijuana Policy Group. URL: https://goo.gl/TxHcgm

McLaughlin, H. (2009): What's in a name: 'Client', 'patient', 'customer,' 'consumer', 'expert by experience', 'service user'-What's Next? The British Journal of Social Work, 39(6), 1101-1117. https://doi.org/10.1093/bjsw/ bcm 155

Melamede, R. (2005): Cannabis and tobacco smoke are not equally carcinogenic. Harm Reduction Journal, 2, 21. https://doi.org/10.1186/1477$7517-2-21$

Molina, N. (1988): L’automédication. Paris: PUF (Coll: Les champs de la santé).

Montastruc, J. L. - Bagheri, H. - Geraud, T. - Lapeyre-Mestre, M. (1997): Pharmacovigilance of self-medication. Thérapie, 52(2), 105-110.

Morral, A. R. - McCaffrey, D. F. - Paddock, S. M. (2002): Reassessing the marijuana gateway effect. Addiction, 97(12), 1493-1504. https://doi. org/10.1046/j.1360-0443.2002.00280.x

Morgan, C. J. A. - Das, R. K. - Joye, A. - Curran, H. V. - Kamboj, S. K. (2013): Cannabidiol reduces cigarette consumption in tobacco smokers: Preliminary findings. Addictive Behaviors, 38(9), 2433-2436. https://doi. org/10.1016/j.addbeh.2013.03.011

NIDA (2016): The science of drug abuse and addiction: The basics. URL: https://goo.gl/CbGfiK

Nutt, D. J. - King, L. A. - Phillips, L. D. (2010): Drug harms in the UK: A multicriteria decision analysis. The Lancet, 376(9752), 1558-1565. https:// doi.org/10.1016/S0140-6736(10)61462-6

Pierron, J. P. (2007): Une nouvelle figure du patient? Les transformations contemporaines de la relation de soins. Sciences Sociales et Sante, 25(2), 43-66. https://doi.org/10.1684/sss.2007.0203

Pokrywka, M. - Góralska, J. - Solnica, B. (2016): Cannabinoids - a new weapon against cancer? Postepy Higieny I Medycyny Doswiadczalnej (Online), 70(0), 1309-1320. https://doi.org/10.5604/17322693.1227443

Pope, H. G. - Yurgelun-Todd, D. (1996): The residual cognitive effects of heavy marijuana use in college students. JAMA: The Journal of the American Medical Association, 275(7), 521-527. https://doi.org/10.1001/ jama.1996.03530310027028.

Raynaud, D. (2008): Les déterminants du recours à l'automédication. Revue Française Des Affaires Sociales, (1), 81-94. URL: https://goo.gl/CEgEXy

Reichel, J. (2009): Kapitoly metodologie sociálnich výzkumu் [Chapters of the social research methodology]. Praha: Grada.

Schweim, H. - Ullmann, M. (2015): Media influence on risk competence in self-medication and self-treatment. German Medical Science: GMS E-Journal, 13, Doc10.

Sheble, L. - Wildemuth, B. (2009): Research diaries. In Wildemuth, B. (Ed.). Applications of social research methods to questions in information and library science. Santa Barbara: Libraries Unlimited, 211-221.

Shrivastava, A. - Johnston, M. - Tsuang, M. (2011): Cannabis use and cognitive dysfunction. Indian Journal of Psychiatry, 53(3), 187-91. https://doi. org/10.4103/0019-5545.86796

Strauss, A. L. - Corbin, J. (1998): Basics of qualitative research techniques and procedures for developing Grounded Theory. London: Sage Publications.
Thompson, C. L. (Ed.). (2015): Self-medication in the nineteenth century. In Patient Expectations. Amherst: University of Massachusetts Press, 33-48.

Van der Geest, S. (2010): Patients as co-researchers? Views and experiences in Dutch medical anthropology. In Fainzang, S. - Hem, H. E. - Risor, M. B. (Eds.) The taste for knowledge: Medical anthropology facing medical realities. Copenhagen: Aarhus University Press, 97-110.

WMA (1981): Declaration of Lisbon on the rights of the patient. URL: https:// goo.gl/JThs4Z.

Yasukawa, K. (2014): Cannabinoids as seed compounds for the cancer treatment. Forensic Toxicology, (32), 189. https://doi.org/10.1007/s11419014-0234-9

Zábranský, T. (2003): Drogová epidemiologie [Drug epidemiology]. Olomouc: Palacký University Olomouc.

Zavázalová, H. (1992): Vybrané kapitoly ze sociálního lékařství [Selected chapters from social medicine]. Praha: Karolinum.

\section{AUTHORS}

Bláhová, Barbora (1987, Prague, Czech Republic) has studied general anthropology at the Faculty of Humanites of the Charles University in Prague. Interested in medical anthropology, therapeutical potential of altered states of consciousness and ethnobotany, she has worked as a freelance journalist and media communication consultant for various organizations active in the field of drug policy. She is currently a vice chair of Legalizace.cz, a non-profit association that focuses mainly on issues related to cannabis legislation in the Czech Republic.

Horák, Miroslav (1981, Zlín, Czech Republic), research assistant at the Department of Languages and Cultural Studies, Faculty of Regional Development and International Studies, Mendel University in Brno. He graduated in Master's degree programs. In 2004, he completed Secondary Schools Education (Czech Language and Essentials of Social Sciences) at the Faculty of Arts, University of Ostrava (diploma Thesis: Gary Snyder's Ecopoetics). In 2006, he graduated in Social and Cultural Ecology at the Faculty of Humanities, Charles University (diploma thesis: Plants of Transformation: The Use of Plant Hallucinogens by Mexican Indians in Oaxaca and Mestizos in Peru). In 2010, he completed doctoral studies in General Anthropology - Integral Study of Humans at the same faculty (diploma thesis: Takiwasi Case: Specific Research on Drug Addiction Treatment by the Traditional Indigenous Medicine of the Peruvian Amazon). Currently, he focuses in ethnobotanics, medical anthropology, and drug addiction treatment. He published several books, e.g. The House of Song, A Reader in Ethnobotany and Phytotherapy or Etnobotánica y fitoterapia en América.

Verter, Nahanga (1980, Mou Village, Nigeria) obtained a BSc Regional Development, MSc Socioeconomic and Environmental Development of Regions, and Ph.D. Business Management and Economics at Mendel University in Brno, Czech Republic. He is currently lecturing at the Faculty of Regional Development and International Studies, Mendel University in Brno, Czech Republic. His research interests include agricultural economics, global trade and socioeconomic development. 